\title{
ANALISIS PELAKSANAAN PERJANJIAN JAM KERJA ANTARA PERUSAHAAN DENGAN PEKERJA DI PT. PLASINDO LESTARI DIHUBUNGKAN DENGAN PASAL 77 UNDANG-UNDANG NOMOR 13 TAHUN 2003 TENTANG KETENAGAKERJAAN
}

\author{
Muhamad Abas, S.H., M.H Email : muhamad.abas@ubpkarawang.ac.id \\ Sartika Dewi,S.ST., M.H Email : sartikadewi@ubpkarawang.ac.id \\ Yusuf Rizki, S.H Email : yusufrizki@mhs.ubpkarawang.ac.id \\ Fakultas Hukum Universitas Buana Perjuangan Karawang
}

\begin{abstract}
ABSTRAK
Perjanjian adalah suatu perbuatan dengan mana satu orang atau lebih mengikatkan dirinya terhadap satu orang lain atau lebih. Di Dalam Pasal 1 angka (14) Undang-undang No.13 Tahun 2003 Tentang Ketenagakerjaan bahwa Perjanjian Kerja adalah perjanjian antara pekerja atau buruh dengan pengusaha atau pemberi kerja yang memuat syarat-syarat kerja, hak, dan kewajiban para pihak. Identifikasi Masalah 1. Bagaimanakah pelaksanaan perjanjian kerja dengan perusahaan di PT Plasindo Lestari Menurut Perjanjian Waktu Kerja? 2. Apakah yang menyebabkan ketidaksesuain jam kerja di PT Plasindo Lestari? Penelitian ini menggunakan Metode Pendekatan secara yuridis- Empiris, Spesifikasi Penelitian yang digunakan bersifat deskriptif, dan data yang diolah adalah deskriptif kualitatif isi sesuai dengan tujuan penelitian yang selanjutnya dikonstruksikan dalam suatu kesimpulan perjanjian kerja dengan perusahaan sudah tidak asing lagi. Perjanjian kerja bersama merupakan hasil antara pihak pengusaha dan pihak pekerja yang diwakili oleh serikat pekerja. Perjanjian kerja bersama di dalam Undang-Undang Nomor 13 Tahun 2003 tercantum dalam pasal 116 sampai pasal 135, yang mengatur tentang persyaratan yang harus di penuhi untuk pembuatan suatu perjanjian kerja bersama.Hasil Penelitian penulis adalah di dalam perkara perusahaan mengenai jam kerja yang tidak sesuai karena di perusahaan PT Plasindo Lestari mengenai jam kerja paling banyak 1 (satu) Hari 12 (Dua Belas) Jam Dan 1 (satu) Minggu 72 (Tujuh Puluh Dua) Jam yang seharusnya didalam Undang-Undang Nomor 13 Tahun 2003 Tentang KetenagaKerjaan Pasal 77 Ayat (2) waktu kerja lembur hanya dapat dilakukan paling banyak 3 (tiga) jam dalam 1 (satu) hari dan 14 (empat belas) jam dalam 1 (satu) minggu.
\end{abstract}

Kata Kunci : Perjanjian, Perusahaan, Jam kerja

Jurnal Justisi Hukum ISSN 2528-2638 Vol 6, No. 2, September 2021 
ANALISIS PELAKSANAAN PERJANJIAN JAM KERJA ANTARA PERUSAHAAN DENGAN PEKERJA DI PT PLASINDO LESTARI DIHUBUNGKAN DENGAN PASAL 77 UNDANGUNDANG NOMOR 13 TAHUN 2003 TENTANG KETENAGAKERJAAN: M. Abas., Sartika Dewi, Yusuf Rizki

\section{ABSTRACT}

An agreement is an act by which one or more persons bind themselves to one or more other persons. In Article 1 number (14) of Law No. 13 of 2003 concerning Manpower, it is stated that a Work Agreement is an agreement between a worker or laborer and an entrepreneur or employer that contains the terms of work, rights and obligations of the parties. Identification of Problems 1. How is the implementation of the work agreement with the company at PT Plasindo Lestari according to the Working Time Agreement? 2. What causes the incompatibility of working hours at PT Plasindo Lestari? This study uses a juridical-empirical approach, the research specifications used are descriptive, and the data processed is descriptive qualitative content in accordance with the research objectives which are then constructed in a conclusion of a work agreement with a familiar company. Collective labor agreement is the result between the employer and the workers represented by the trade union. Collective labor agreements in Law No. 13 of 2003 are listed in articles 116 to 135, which regulate the requirements that must be met for making a collective work agreement. at PT Plasindo Lestari regarding working hours at most 1 (one) Day 12 (Twelve) Hours and 1 (one) Week 72 (Seventy Two) Hours which should be in Law Number 13 of 2003 concerning Manpower Article 77 Paragraph (2) overtime can only be done for a maximum of 3 (three) hours in 1 (one) day and 14 (fourteen) hours in 1 (one) week.

Keywords: Agreement, Company, Working Hours 
ANALISIS PELAKSANAAN PERJANJIAN JAM KERJA ANTARA PERUSAHAAN DENGAN PEKERJA DI PT PLASINDO LESTARI DIHUBUNGKAN DENGAN PASAL 77 UNDANGUNDANG NOMOR 13 TAHUN 2003 TENTANG KETENAGAKERJAAN: M. Abas., Sartika Dewi, Yusuf Rizki

\section{PENDAHULUAN}

Setiap manusia selalu membutuhkan biaya untuk memenuhi kebutuhan hidupnya. Untuk mendapatkan biaya hidup seseorang perlu bekerja. Bekerja dapat dilakukan secara mandiri atau bekerja kepada orang lain. Bekerja kepada orang lain dapat dilakukan dengan bekerja kepada negara yang selanjutnya disebut sebagai pegawai atau bekerja kepada orang lain (swasta) yang disebut sebagai buruh atau pekerja. Buruh/pekerja dalam melakukan pekerjaan, ${ }^{1}$ terlebih dahulu membicarakan mengenai apa yang harus dilakukan dengan apa yang tidak boleh dilakukan, serta membicarakan mengenai hak-hak dari buruh yang harus dipenuhi oleh pengusaha melalui perundingan bersama atau melalui perjanjian kerja bersama yang dibuat antara organisasi buruh dengan pengusaha/organisasi pengusaha. $^{2}$
Pasal 1 angka 17 Undang-Undang Nomor. 13 Tahun 2003 tentang Ketenagakerjaan, mendefinisikan serikat pekerja/serikat buruh adalah organisasi yang dibentuk dari, oleh dan untuk pekerja/buruh baik di perusahaan maupun di luar perusahaan, yang bersifat bebas, ${ }^{3}$ terbuka, mandiri, demokratis dan bertanggung jawab guna memperjuangkan, membela serta melindungi hak dan kewajiban pekerja/buruh serta meningkatkan kesejahteraan pekerja/buruh dan keluarganya. Pasal 1 angka 21 UndangUndang Nomor. 13 Tahun 2003 tentang ketenagakerjaan memberikan definisi mengenai perjanjian kerja bersama sebagai perjanjian yang merupakan hasil perundingan antara serikat pekerja/serikat buruh atau beberapa serikat/serikat buruh yang tercatat pada instansi yang bertanggung jawab di bidang ketenagakerjaan dengan pengusaha, beberapa pengusaha, atau perkumpulan pengusaha yang membuat syarat-syarat kerja,hak dan kewajiban kedua belah pihak. Dengan demikian peran para buruh/pekerja

3 Khakim, Abdul, Pengantar Hukum Ketenagakerjaan Indonesia Berdasarkan Undang- Undang Nomer 13 Tahun 2003, Bandung: PT. Citra Aditya Bakti, 2003.
1 Abdul Khakim, Dasar-Dasar Hukum Ketenagakerjaan Indonesia, PT Citra Aditya Bakti, Bandung, 2009.

\footnotetext{
${ }^{2}$ Abdul Rachmad Budiono, Hukum Perburuhan
Indonesia, PT RajaGrafindo Persada, Jakarta,

${ }^{2}$ Abdul Rachmad Budiono, Hukum Perburuhan
Indonesia, PT RajaGrafindo Persada, Jakarta, 2008.
} 
ANALISIS PELAKSANAAN PERJANJIAN JAM KERJA ANTARA PERUSAHAAN DENGAN PEKERJA DI PT PLASINDO LESTARI DIHUBUNGKAN DENGAN PASAL 77 UNDANGUNDANG NOMOR 13 TAHUN 2003 TENTANG KETENAGAKERJAAN: M. Abas., Sartika Dewi, Yusuf Rizki

yang diwakilkan oleh serikat buruh/pekerja serta para pengusaha yang diwakili beberapa pengusaha atau perkumpulan pengusaha sangat berarti dalam membuat perjanjian kerja bersama yang kesemuanya telah diatur dalam undang-undang ketenagakerjaan.

Dalam Hukum Ketenagakerjaan diatur dalam Undang-undang Nomor 13 Tahun 2003 tentang ketenagakerjaan. Pembangunan ketenagakerjaan sebagai bagian integral dari pembangunan nasional berdasarkan pancasila dan Undang-Undang Dasar Negara RI Tahun 1945, dilaksanakan dalam rangka pembangunan manusia Indonesia seutuhnya dan pembangunan masyarakat Indonesia seluruhnya untuk meningkatkan harkat, martabat, dan harga diri tenaga kerja serta mewujutkan masyarakat sejahtera, adil, makmur, dan merata baik materiil maupun sepiritual (Penjelasan Umum atas Undang-Undang Nomor 13 Tahun 2003 Tentang Keteagakerjaan. ${ }^{4}$

Di dalam penerimaan tenaga kerja oleh suatu perusahaan digunakan suatu perjanjian yang disebut perjanjian kerja.

\footnotetext{
${ }^{4}$ Subekti,HukumPerjanjian,Jakrta,PT,Intermasa
}

Perjanjian pada dasarnya adalah suatu peristiwa dimana seseorang berjanji kepada seorang lain atau dimana dua orang itu saling berjanji untuk melaksanakan suatu hal. Dari peristiwa ini, timbulah suatu hubungan antara dua orang tersebut yang dinamakan perikatan.

Perjanjian itu menerbitkan suatu perikatan antar dua orang yang membuatnya.Dalam bentuknya perjanjian itu berupa suatu rangkaian perkataan yang mengandung janji-janji atau kesanggupan yang diucapkan atau ditulis. Dengan demikian hubungan antar perikatan dan perjanjian adalah bahwa perjanjian itu menerbitkan perikatan. Perjanjian adalah sumber perikatan, disampingnya sumbersumber lain.

Peraturan mengenai jam kerja telah diatur secara khusus dalam Undang-Undang Nomor 13 Tahun 2003 tentang ketenagakerjaan pasal 77 sampai pasal 85 . Dimana, Pasal 77 ayat 1, Undang-Undang Nomor 13 Tahun 2003 mewajibkan setiap pengusaha untuk melaksanakan ketentuan jam kerja. Ketentuan jam kerja ini mengatur 2 sistem, yaitu: 7 jam kerja dalam 1 hari atau 40 jam kerja dalam 1 minggu untuk 6 hari kerja dalam 1 minggu; atau 8 jam kerja 
ANALISIS PELAKSANAAN PERJANJIAN JAM KERJA ANTARA PERUSAHAAN DENGAN PEKERJA DI PT PLASINDO LESTARI DIHUBUNGKAN DENGAN PASAL 77 UNDANGUNDANG NOMOR 13 TAHUN 2003 TENTANG KETENAGAKERJAAN: M. Abas., Sartika Dewi, Yusuf Rizki

dalam 1 hari atau 40 jam kerja dalam 1

minggu untuk 5 hari kerja dalam 1 minggu.

Pada kedua sistem jam kerja tersebut juga diberikan batasan jam kerja yaitu 40 (empat puluh) jam dalam 1 (satu) minggu. Apabila melebihi dari ketentuan waktu kerja tersebut, maka waktu kerja biasa dianggap masuk sebagai waktu kerja lembur sehingga pekerja atau buruh berhak atas upah lembur. Ketentuan waktu kerja diatas juga hanya mengatur batas waktu kerja untuk 7 atau 8 jam sehari dan 40 jam seminggu dan tidak mengatur kapan waktu atau jam kerja dimulai dan berakhir. Pengaturan mulai dan berakhirnya waktu atau jam kerja setiap hari dan selama kurun waktu seminggu, harus diatur secara jelas sesuai dengan kebutuhan oleh para pihak dalam Perjanjian Kerja, Peraturan Perusahaan (PP) atau Perjanjian Waktu Kerja . Karena itu apabila salah satu pihak biasanya pengusaha ingin merubah jam kerja maka harus berdasarkan kesepakatan dengan perwakilan pekerja atau Surat Perjanjian serta melakukan sosialisasi kepada pekerjanya yang kemudian dituangkankan dalam kesepakatan bersama atau Perjanjian Kerja Bersama.
Hipotesa Penulis bentuk perjanjian yang dilakukan PT Plasindo Lestari tidak sesuai dengan Undang-Undang Nomor 13 Tahun 2003 tentang KetenagaKerjaan Didalam Pasal 78 Menyebutkan Ketentuan Lembur sedangkan jika melihat dilapangan untuk mengetahui jam Lembur di PT Plasindo Lestari banyak 1 (satu) Hari 12 (Dua Belas) Jam Dan 1 (satu) Minggu 72 (Tujuh Puluh Dua) Jam.

Berdasarkan uraian-uraian tersebut di atas, maka proposal skripsi ini diberi judul Tinjauan Yuridis tentang perjanjian kerja antara perusahaan dengan pekerja Di PT. PLASINDO LESTARI Dihubungkan dengan Undang-Undang Nomor 13 Tahun 2003 Tentang KetenagaKerjaan.

\section{PERMASALAHAN}

1. Bagaimanakah pelaksanaan perjanjian kerja dengan perusahaan di PT. Plasindo Lestari Menurut Perjanjian Waktu Kerja ?

2. Apakah yang menyebabkan ketidaksesuain jam kerja di PT. Plasindo Lestari?

\section{METODE PENELITIAN}


ANALISIS PELAKSANAAN PERJANJIAN JAM KERJA ANTARA PERUSAHAAN DENGAN PEKERJA DI PT PLASINDO LESTARI DIHUBUNGKAN DENGAN PASAL 77 UNDANGUNDANG NOMOR 13 TAHUN 2003 TENTANG KETENAGAKERJAAN: M. Abas., Sartika Dewi, Yusuf Rizki

Penelitian ini merupakan penelitian

yang bersifat pendekatan yuridis-empiris, yakni penelitian terhadap efektivitas hukum merupakan penelitian yang membahas bagaimana hukum beroprasi dalam masyarakat, penelitian seperti ini sangat relevan di negara-negara berkembang seperti di Indonesia Dengan pendekatan yuridis empiris dapat menunjang keakuratan data dan mencari kejelasan untuk mengetahui bagaimana PT Plasindo Lestari perjanjian kerja dengan perusahaan.

Selanjutnya mengenai Spesifikasi penelitian ini saya menggunakan pendekatan deskriptif. Penelititan deskriptif ini pada umumnya bertujuan untuk mendeskripsikan secara sistematis, faktual, dan akurat terhadap suatu obyek tertentu. Yang dalam penelitian ini, penulis akan mendeskripsikan mengenai Perjanjian Kerja Dengan Perusahaan.

Penulis mengumpulkan data dari hasil wawancara dari narasumber dipadukan dengan membaca, mencatat dan mengutip dari buku-buku dan peraturan PerUndangUndangan yang sesuai dan berhubungan dengan masalah yang akan diteliti oleh penulis. Pengumpulan data sekunder dilakukan dengan mempelajari materimateri yang berupa bahan-bahan tertulis,baik berupa buku-buku, majalah,jurnal, artikel-artikel dari internet maupun peraturan perUndang-Undangan yang berkaitan dengan materi penelitian.

Analisis data yang peneliti gunakan dalam penelitian ini adalah metode analisis data secara deskriptif kualitatif, yaitu segala sesuatu yang dinyatakan responden, baik secara tertulis maupun secara lisan serta prilaku nyata yang dipelajari dan diteliti sebagai sesuatu yang utuh. Kemudian data yang telah diperoleh dari hasil penelitian lalu diolah.

\section{PEMBAHASAN}

A. Pelaksanaan perjanjian kerja di PT. Plasindo Lestari Menurut Perjanjian Waktu Kerja di hubungkan dengan Undang-Undang Pasal 77 UndangUndang Nomor 13 Tahun 2003 Tentang KetenagaKerjaan

Berdasarkan peraturan ketenagakerjaan yang berlaku, jam kerja efektif perusahaan ditetapkan 8 ( Delapan ) jam kerja untuk 5 (lima ) hari dan 4 (empat ) jam kerja untuk 1 ( satu ) hari dalam 1 (satu minggu ). Jam masuk adalah jam ( 08.00 ) dan jam pulang adalah jam ( 17.00 ) untuk 
ANALISIS PELAKSANAAN PERJANJIAN JAM KERJA ANTARA PERUSAHAAN DENGAN PEKERJA DI PT PLASINDO LESTARI DIHUBUNGKAN DENGAN PASAL 77 UNDANGUNDANG NOMOR 13 TAHUN 2003 TENTANG KETENAGAKERJAAN: M. Abas., Sartika Dewi, Yusuf Rizki

hari sabtu jam pulang jam (12.00). Waktu istirahat pada hari Senin hingga hari Kamis ditetapkan selama 60 ( enam puluh ) Menit, yaitu pada pukul ( 12.00 ) hingga pukul (13.00 ). Waktu istirahat pada hari Jum'at ditetapkan selama 90 ( sembilan puluh ) menit, yaitu pada pukul ( 11.30 ) hingga pukul (13.00).

Setelah berakhirnya jangka waktu perjanjian kerja kontrak, perjanjian kerja ini dapat diperpanjang jika Pihak Pertama masih membutuhkan Pihak Kedua dan Pihak Pertama juga menyatakan kesediaannya. Jika setelah berakhirnya perjanjian kerja ke-2 ternyata pihak pertama atau perusahaan masih membutuhkan pihak kedua atau pekerja maka pihak pertama akan mengangkat pihak kedua sebagai karyawan tetap pada perusahaan PT Plasindo Lestari. Akan tetapi jika setelah berakhirnya perjanjian kerja ke-2 ternyata pihak kedusa tidak diajukan untuk pengangkatan sebagai karyawan tetap oleh pihak pertama, maka perjanjian kerja kontrak akan berakhir bersamaan dengan berakhirnya waktu perjanjian tersebut.

PT. Plasindo Lestari atau pihak yang memberikan pekerjaan memberikan upah/gaji pokok kepada pihak pekerja sebesar (Rp. 4.200.000,-) ( Empat Juta Dua Ratus Ribu Rupiah ) setiap bulan. yang harus dibayarkan pada tanggal terakhir setiap bulan setelah dipotong pajak pendapatan sesuai peraturan perpajakan di Indonesia. Selain gaji pokok, pekerja juga berhak mendapatkan tunjangan-tunjangan sebagai berikut :

1. Tunjangan Kesehatan sebesar ( Rp. 100.000,- ) ( seratus ribu rupiah ).

2. Tunjangan kerja lembur sebesar (Rp. 25.000,-) ( tujuh ribu rupiah ) setiap jam Pembayaran tunjangan-tunjangan tersebut akan disatukan dengan pembayaran gaji pokok yang akan diterima Pihak Kedua pada tanggal terakhir setiap bulan.

Pihak pekerja diharuskan masuk kerja lembur jika tersedia pekerjaan yang harus segera diselesaikan atau bersifat mendesak (urgent). Sebagai imbalan kerja lembur, pihak perusahaan akan membayar pihak pekerja sebesar ( Rp. 22.000 - ) ( dua puluh dua ribhu rupiah ) setiap jam lembur. Pembayaran upah lembur akan disatukan dengan pembayaran gaji yang akan diterima PIHAK PERTAMA pada tanggal terakhir setiap bulan. 
ANALISIS PELAKSANAAN PERJANJIAN JAM KERJA ANTARA PERUSAHAAN DENGAN PEKERJA DI PT PLASINDO LESTARI DIHUBUNGKAN DENGAN PASAL 77 UNDANGUNDANG NOMOR 13 TAHUN 2003 TENTANG KETENAGAKERJAAN: M. Abas., Sartika Dewi, Yusuf Rizki

Selama masa berlakunya ikatan perjanjian kerja ini pihak pekerja tidak dibenarkan melakukan kerja rangkap di perusahaan lain manapun juga dengan mengemukakan dalih atau alasan apa pun juga.

Perjanjian kerja di lingkungan perusahaan PT. Plasindo Lestari penulis membahas dari waktu kerja, jenis Pekerjaaan, sistem pengupahan yang dijalankan, hak dan kewajiban masingmasing pihak.

a) Waktu Kerja PT Plasindo Lestari

Setelah menyepakati perjanjian kerja pekerja langsung melaksanakan pekerjaan sesuai dengan waktu yang tertuang dalam perjanjian kerja yakni masuk jam ( 08.00 ) dan jam pulang jam ( 17.00 ) untuk hari sabtu jam pulang jam (12.00). Waktu istirahat pada hari Senin hingga hari Kamis ditetapkan selama 60 ( enam puluh ) Menit, yaitu pada pukul ( 12.00 ) hingga pukul (13.00 ). Waktu istirahat pada hari Jum'at ditetapkan selama 90 ( sembilan puluh ) menit, yaitu pada pukul ( 11.30 ) hingga pukul (13.00). 8 ( Delapan ) jam kerja untuk 5 (lima) hari dan 4 (empat ) jam kerja untuk 1 ( satu ) hari dalam 1 (satu minggu ) ketentuan ini berlaku bagi seluruh pekerja. Akan tetapi saat perusahaan mengalami Penaikan permintaan atau Kenaikan Orderan dari phak custamer stok barang pihak perusahaan PT Plasindo Lestari seringkali merubah waktu kerja secara sepihak. Dengan adanya penentuan waktu kerja sepihak pekerja sering kali mengalami . penambahan jam kerja atau lembur dan tidak sesuai dengan PKB. Dalam 1 minggu pekerja hanya dipekerjakan 84 Jam sehingga pekerja hanya diliburkan pada hari minggu, jadi satu bulan hanya bekerja 26, sebagian pekerja mengalami sanksi dari pihak management PT Plasindo Lestari serta penulis pun terkena Oudit (Buyer Unilever).

b) Jenis Pekerjaan

Setiap pekerja melaksanakan kewajibannya sesuai dengan bagian masingmasing. Di PT Plasindo Lestari terdiri dari 5 bagian yakni Bag making, Sliter,Printing,Blown Flim, Extrusion. Setiap pekerja dalam satu hari contohnya di bagian Bag Making ditargetkan untuk menyelesaikan 200 Ribu Pcs

c) Jam kerja 
ANALISIS PELAKSANAAN PERJANJIAN JAM KERJA ANTARA PERUSAHAAN DENGAN PEKERJA DI PT PLASINDO LESTARI DIHUBUNGKAN DENGAN PASAL 77 UNDANGUNDANG NOMOR 13 TAHUN 2003 TENTANG KETENAGAKERJAAN: M. Abas., Sartika Dewi, Yusuf Rizki

Sistem pengupahan di PT Plasindo Lestari telah tertuang dalam isi perjanjian kerja. akan tetapi jika perusahaan mengalami tingginya permintaan order produksi maka pihak perusahaan mempekerjakan karyawan secara terus menerus dan tidak sesuai dengan isi perjanjian. upah yang dibayarkan berdasarkan masa kerja. besaran upah berubah dihitung berdasarkan upah harian/jam lermbur sebesar Rp. 25.000,00 per jam untuk yang level Helper atau asisten Operator berlaku bagi pekerja kontrak dan pekerja tetap dan Rp. 30.000, per jam untuk yang level Operator- berlaku bagi pekerja yang msudah karyawan tetap

Menurut Bapak Agus Sutrisno ST selaku Section Head Bag making di PT. Plasindo Lestari terjadinya perubahan waktu kerja sepihak di PT. Plasindo Lestari karena melonjaknya orderan di PT Plasindo Lestari. $^{5}$

Menurut sebagian pekerja, diantaranya pekerja yang bernama Bapak. Wiro selaku pekerja di PT Plasindo lestari beliau bekerja sudah 10 ( Sepuluh ) tahun

5 Wawancara Kepada Bapa Agus Sutrisno Selaku section Head Bag making,diakses pada tanggal 27 Oktober 2020 Pukul 12.10 sejak tahun 2010 sampai sekarang. Adanya perubahan waktu kerja sepihak di PT. Plasindo Lestari terjadi sejak 5 ( lima) tahun terakhir. Tidak jelasnya waktu jam kerja mengakibatkan banyak pekerja yang Komplen terhadap kebijakan isi PKB (Perjanjian Kerja Bersama) yang ada di PT Plasindo Lestari. ${ }^{6}$

Menurut saudara Karmin bekerja sejak tahun 2019 sampai sekarang. Dengan adanya perubahan waktu jam kerja sepihak yang dilakukan pihak perusahaan tidak memenuhi kesepakatan pekerja.pekerja tidak mendapatkan pekerjaan yang dijanjikan. berdampak pada besaran jam kerja. Jam kerja yang di sepakati dalam perjanjian kerja yaitu dalam hari senin Jam 08.00 sampai dengan Jam 16.00 akan tetapi tidak sesuai dengan isi PKB. Pekerja mengalami jam kerja lembur dalam 1 hari 12 jam sedangkaan pekerja dalam 1 minggu bekerja selama 84 jam, Hal ini berlaku pula untuk pekerja yang masih dalam masa kontrak, saudara karmin bekerja dibagian Bag Making sebagai Helper (Asisten Operator )

6 Wawancara Kepada Bapa Wiro Selaku Pekerja PT Plasindo Lestari,diakses pada tanggal 27 Oktober 2020 Pukul 12.15 
ANALISIS PELAKSANAAN PERJANJIAN JAM KERJA ANTARA PERUSAHAAN DENGAN PEKERJA DI PT PLASINDO LESTARI DIHUBUNGKAN DENGAN PASAL 77 UNDANGUNDANG NOMOR 13 TAHUN 2003 TENTANG KETENAGAKERJAAN: M. Abas., Sartika Dewi, Yusuf Rizki

Menurut saudara Pak dadang bekerja sejak tahun 2012 sampai sekarang. Dengan adanya perubahan waktu jam kerja sepihak yang dilakukan pihak perusahaan tidak memenuhi kesepakatan pekerja.pekerja tidak mendapatkan pekerjaan yang dijanjikan. berdampak pada besaran jam kerja. Jam kerja yang di sepakati dalam perjanjian kerja yaitu dalam hari senin Jam 08.00 sampai dengan Jam 16.00 akan tetapi tidak sesuai dengan isi PKB. Pekerja mengalami jam kerja lembur dalam 1 hari 12 jam sedangkaan pekerja dalam 1 minggu bekerja selama 84 jam ,Hal ini berlaku pula untuk pekerja yang masih dalam masa kontrak, saudara karmin bekerja dibagian Teknik (Maintenance)

Menurut Bapak. Herman selaku personalia, adanya penentuan jam kerja sepihak di PT Plasindo Lestari sangat merugikan pekerja . Penyelesaian Kasus ini jadi bertabrakan dan tidak sesuai dengan isi PKB. Karena sifat kerjanya sesuai target dari pihak management PT Plasindo Lestari terkait kurangnya personil dalam bekerja Pihak Management terpaksa Mempekerjakan Karyawan yang ada. Sehingga menyalahkan pihak personalia ssering terjadi perselisihan antara pekerja dengan perusahan mengenai aturan jam kerja diperusahaan PT Plasindo Lestari. ${ }^{7}$

Menurut Penulis bekerja sejak tahun 2017 sampai dengan 23 Agustus 2020. Dengan adanya perubahan waktu jam kerja sepihak yang dilakukan pihak perusahaan tidak memenuhi kesepakatan pekerja.pekerja tidak mendapatkan pekerjaan yang dijanjikan. berdampak pada besaran jam kerja. Jam kerja yang di sepakati dalam perjanjian kerja yaitu dalam hari senin Jam 08.00 sampai dengan Jam 16.00 akan tetapi tidak sesuai dengan isi PKB. Pekerja mengalami jam kerja lembur dalam 1 hari 12 jam sedangkaan pekerja dalam 1 minggu bekerja selama 84 jam ,Hal ini berlaku pula untuk pekerja yang masih dalam masa kontrak, penulis bekerja dibagian Bag Making

\section{B. Apakah yang menyebabkan ketidak sesuain jam kerja di PT Plasindo Lestari}

Hubungan antara pengusaha dengan pekerja dalam hal ketenagakerjaan di Indonesia sangatlah memprihatinkan. Hal ini dikarenakan paradigma pengusaha yang

7 Wawancara Kepada Bapak. Herman selaku personalia,diakses pada tanggal 28 Oktober 2020 pukul 12.30 
ANALISIS PELAKSANAAN PERJANJIAN JAM KERJA ANTARA PERUSAHAAN DENGAN PEKERJA DI PT PLASINDO LESTARI DIHUBUNGKAN DENGAN PASAL 77 UNDANGUNDANG NOMOR 13 TAHUN 2003 TENTANG KETENAGAKERJAAN: M. Abas., Sartika Dewi, Yusuf Rizki

merasa memiliki kedudukan di atas pekerja karena pengusaha yang memberikan upah kepada pekerja, adapun hubungan pemberi kerja dengan pekerja tercipta dikarenakan adanya suatu perjanjian kerja yang mengikat kedua belah pihak yang di dalamnya memuat aturan mengenai pekerjaan, upah serta perintah yang telah disepakati bersama oleh pemberi kerja dengan pekerja. Syarat sahnya suatu perjanjian kerja terdapat dalam Pasal 52 ayat (1) Undang-Undang Nomor 13 Tahun 2003 tentang Ketenagakerjaan.

Setelah adanya perjanjian kerja, pihak pemberi kerja pun berkewajiban untuk memberikan upah atau imbalan dalam bentuk lain kepada pekerja dikarenakan telah melakukan pekerjaannya dengan melihat juga waktu kerja yang telah ditentukan.

Dalam pasal 77 yang tertera dalam Undang-undang Ketenagakerjaan Nomor 13 tahun 2003 telah menyebutkan :

1.Setiap pengusaha wajib melaksanakan ketentuan waktu kerja

2.Waktu kerja sebagaimana dimaksud dalam ayat ( 1 ) meliputi : a.7 ( tujuh ) jam 1 (satu ) hari dan 40 ( empat puluh ) jam 1 ( satu minggu untuk 6 ( enam ) hari kerja dalam 1 (satu ) minggu; atau

b.8 ( delapan ) jam 1 ( satu ) hari dan 40 ( empat puluh ) jam 1 (satu ) minggu untuk 5 ( lima ) hari kerja dalam 1 ( satu ) minggu.

3.Ketentuan waktu kerja sebagaimana dimaksud dalam ayat ( 2 ) tidak berlaku bagi sektor usaha atau pekerjaan tertentu.

4.Ketentuan mengenai waktu kerja pada sektor usaha atau pekerjaan tertentu sebagaimana dimaksud dalam ayat ( 3 ) diatur dengan keputusan menteri.

Adapun pengusaha yang memperkerjakan pekerja/buruh melebihi waktu kerja sebagaimana dimaksud dalam Pasal 77 ayat (2) Undang-Undang Nomor. 13 Tahun 2003 tentang Ketenagakerjaan disebut waktu kerja lembur yang harus memenuhi syarat yang terdapat dalam Pasal 78 ayat (1) Undang-Undang Nomor. 13 Tahun 2003 tentang Ketenagakerjaan.

Dimana apabila pengusaha memperkerjakan pekerja/buruh dengan 
ANALISIS PELAKSANAAN PERJANJIAN JAM KERJA ANTARA PERUSAHAAN DENGAN PEKERJA DI PT PLASINDO LESTARI DIHUBUNGKAN DENGAN PASAL 77 UNDANGUNDANG NOMOR 13 TAHUN 2003 TENTANG KETENAGAKERJAAN: M. Abas., Sartika Dewi, Yusuf Rizki

waktu kerja lembur, maka pengusaha diwajibkan untuk membayar kelebihan jam kerjanya dengan upah lembur. Pemberian upah oleh pengusaha kepada pekerja dalam hal ini menimbulkan permasalahan karena sangatlah menyimpang dalam ketentuan Undang-Undang Nomor. 13 Tahun 2003 tentang Ketenagakerjaan dimana dalam hal ini setiap pekerja yang melakukan waktu kerja lembur wajib diberikan upah lembur yang terdapat dalam Pasal 78 ayat (2) Undang-Undang tersebut yang nyatanya terjadi kesenjangan das sollen dengan das sein yaitu antara norma atau peraturan yang ada tidak sesuai dengan yang diterapkan di PT Plasindo Lestari.

Telah disebutkan beberapa peraturan yang membahas tentang perjanjian kerja dan penetuan waktu kerja pekerja. tetapi dengan adanya ketentuan- ketentuan tersebut hendaknya dalam menentukan waktu kerja di PT Plasindo Lestari Indonesia sesuai dengan perjanjian kerja atau peraturan perusahaan yang tetap mengarah pada peraturan undang-undang yang berlaku.

Dalam isi perjanjian PT. Plasindo Lestari dalam menentukan waktu kerja jika dikaitkan pasal 77 ayat 2 maka waktu kerja di PT Plasindo Lestari dalam satu minggu kelebihan 4 jam. Sedangkan dengan adanya penentuan waktu kerja saat melonjaknya permintaan tanpa adanya batasan waktu atau kejelasan waktu tidak sesuai dengan pasal 77 ayat 1.

jika dilihat dari keterangan para pekerja, sebenarnya mereka bersedia melakukan kewajiban sesuai dengan peraturan perusahaan dan perjanjian kerja yang berlaku. Dampak yang dialami pekerja dengan adanya penentuan waktu kerja sepihak dari perusahaan, pekerja merasa hak-hak pekerja tidak dipenuhi oleh pihak perusahaan atau pihak perusahaan tidak melaksanakan kewajiban sesuai dengan perjanjian kerja dan peraturan perusahaan yang disepakati, salah satunya pekerja tidak mendapatkan pekerjaan yang dijanjikan, sehingga berpengaruh pada besaran upah.

1) Faktor kondisi ketenagakerjaan, dimana permintaan akan lapangan pekerjaan sangat tinggi, sedangkan penawaran lapangan pekerjaan rendah.

2) Faktor ekonomi, yaitu pemenuhan kebutuhan dasar bagi kehidupan dasar bagi kehidupan buruh dan keluarganya. 
ANALISIS PELAKSANAAN PERJANJIAN JAM KERJA ANTARA PERUSAHAAN DENGAN PEKERJA DI PT PLASINDO LESTARI DIHUBUNGKAN DENGAN PASAL 77 UNDANGUNDANG NOMOR 13 TAHUN 2003 TENTANG KETENAGAKERJAAN: M. Abas., Sartika Dewi, Yusuf Rizki

3) Persaingan yang ketat untuk memperoleh pekerjaan.

4) Faktor Jam kerja tidak sesuai di PT Plasindo Lestari

5) Faktor Upah Lembur yang tidak pernah dibayar

6) Faktor melebihi waktu jam kerja

Undang-Undang Republik Indonesia Nomor. 13 tahun 2003 tentang Ketenagakerjaan, mengatur dengan tegas dan jelas mengenai pengupahan. 5 Pengusaha dalam memberikan upah kepada pekerja didasarkan atas faktor yang salah satunya yaitu waktu kerja, dimana waktu kerja itu dibagi menjadi 2 menurut Pasal 77 ayat (2) Undang-Undang No. 13 Tahun 2003 tentang Ketenagakerjaan, yaitu:

1) waktu kerja 6 hari kerja dalam satu minggu ialah satu harinya 7 jam dan dalam satu minggu 40 jam.

2) waktu kerja untuk 5 hari dalam satu minggu ialah dalam satu harinya 8 jam dan 40 jam dalam satu minggu.

Pengusaha memungkinkan untuk memperkerjakan pekerjanya melebihi batas waktu kerja yang telah ditentukan, adapun pengusaha yang memperkerjakan pekerja/buruh melebihi waktu kerja sebagaimana dimaksud dalam Pasal 77 ayat (2) Undang-Undang Nomor. 13 Tahun 2003 tentang Ketenagakerjaan disebut waktu kerja lembur, hal ini dilakukan oleh pengusaha untuk dapat mengejar ataupun memenuhi target yang telah ditentukan oleh perusahaan agar dapat tercapai.

Pengusaha dalam memperkerjakan pekerja/buruh diluar waktu kerja wajib

1.memberi upah kerja lembur.

2.memberi kesempatan untuk istirahat secukupnya.

3.memberi makanan dan minuman sekurang-kurang 1400 kalori apabila kerja lembur dilakukan selama 3 (tiga) jam atau lebih. Pemberian makanan dan minuman tidak boleh diganti dengan uang dan cara perhitungannya didasarkan pada upah bulanan, dan cara menghitungnya adalah upah sejam adalah 1/173 kali upah sebulan.

Apabila pengusaha akan melakukan kerja lembur pada hari kerja, maka harus ada perintah tertulis dari pengusaha dan persetujuan tertulis dari pekerja/buruh yang 
ANALISIS PELAKSANAAN PERJANJIAN JAM KERJA ANTARA PERUSAHAAN DENGAN PEKERJA DI PT PLASINDO LESTARI DIHUBUNGKAN DENGAN PASAL 77 UNDANGUNDANG NOMOR 13 TAHUN 2003 TENTANG KETENAGAKERJAAN: M. Abas., Sartika Dewi, Yusuf Rizki

bersangkutan bentuknya adalah dalam bentuk daftar pekerja/buruh, yang selanjutnya ditandatangani oleh pengusaha dan pekerja/buruh yang bersedia bekerja lembur.

Pekerja yang menjalani waktu kerja lembur sepatutnya memperoleh upah terhadap hal tersebut karena telah diatur dalam Pasal 78 ayat (2) UU No. 13 Tahun 2003 tentang Ketenagakerjaan yang mengatakan bahwa pengusaha yang memperkerjakan pekerja/buruh melebihi waktu kerja sebagaimana dimaksud dalam ayat (1) wajib membayar upah kerja lembur, dan ditekankan bahwa pengusaha wajib melaksanakan ketentuan waktu kerja seperti yang terdapat dalam Pasal 77 ayat (1) UU No. 13 Tahun 2003 tentang Ketenagakerjaan

\section{Pasal 33 Peraturan Pemerintah} Nomor 78 Tahun 2015 tentang Pengupahan menyatakan bahwa:

Upah kerja lembur sebagaimana dimaksud dalam Pasal 3 ayat (2) huruf $b$ wajib dibayar oleh Pengusaha yang mempekerjakan Pekerja/Buruh melebihi waktu kerja atau pada istirahat mingguan atau dipekerjakan pada hari libur resmi sebagai kompensasi kepada Pekerja/Buruh yang bersangkutan sesuai dengan ketentuan peraturan perundang-undangan.

Berdasarkan rumusan pasal-pasal tersebut jadi dapat dikatakan bahwa apabila pekerja diberikan waktu kerja lembur oleh pengusaha, maka pengusaha diwajibkan membayar upah terhadap waktu kerja lembur tersebut yang perhitungannya sesuai dengan Pasal 11 Keputusan Menteri Tenaga Kerja dan Transmigrasi Republik Indonesia Nomor Kep. 102/Men/VI/2004 tentang Waktu Kerja Lembur dan Upah Kerja Lembur, yaitu:

1.Perhitungan upah lembur pada hari kerja

a. Untuk jam kerja lembur pertama harus dibayar upah sebesar 1,5 kali upah sejam

b. Untuk setiap jam kerja lembur berikutnya harus dibayar upah sebesar 2 kali upah sejam

2.Perhitungan upah lembur pada waktu kerja 6 hari kerja dan 40 jam seminggu yaitu Perhitungan upah kerja lembur untuk 7 jam pertama dibayar 2 kali uah sejam, dan untuk jam kedelapan dibayar 
ANALISIS PELAKSANAAN PERJANJIAN JAM KERJA ANTARA PERUSAHAAN DENGAN PEKERJA DI PT PLASINDO LESTARI DIHUBUNGKAN DENGAN PASAL 77 UNDANGUNDANG NOMOR 13 TAHUN 2003 TENTANG KETENAGAKERJAAN: M. Abas., Sartika Dewi, Yusuf Rizki

3 kali upah sejam, sedangkan untuk jam lembur kesembilan dan kesepuluh dibayrkan upah sebesar 4 kali upah sejam

\section{Perhitungan upah lembur apabila} hari libur resmi jatuh pada hari kerja terpendek yaitu Perhitungan upah lembur 5 jam pertama dibayar 2 kali upah sejam, jam keenam dibayar 3 kali upah sejam, sedangkan jam lembur ketujuh dan kedelapan 4 kali upah sejam

4.Perhitungan upah kerja lembur apabila waktu kerja 5 hari kerja dan 40 jam seminggu yaitu Perhitungan upah kerja lembur untuk 8 jam pertama dibayar 2 kali upah sejam, jam kesembilan dibayar 3 kali upah sejam, sedangkan jam kesepuluh dan kesebelas dibayar 4 kali upah sejam

\section{Dilihat dari Keputusan Menteri} Tenaga Kerja dan Transmigrasi Republik Indonesia Nomor Kep. 102/Men/VI/2004 tentang Waktu Kerja Lembur dan Upah Kerja Lembur, dapat dikatakan bahwa pengusaha wajib untuk membayarkan upah kerja lembur sesuai dengan pengaturan yang terdapat dalam Keputusan Menteri tersebut, kata wajib yang terdapat dalam pasal tersebut mengisyaratkan bahwa tidak ada alasan apapun bagi pengusaha untuk tidak melaksanakan ketentuan tersebut yang bertujuan untuk memberikan perlindungan hukum bagi para pekerja/buruh yang diberikan waktu kerja lembur.

Kenyataannya hanya terdapat satu pekerja dari empat orang pekerja yang mendapatkan haknya untuk memperoleh upah kerja lembur di PT Plasindo Lestari yang artinya kesadaran pengusaha dalam memenuhi aturan yang berlaku serta menjamin hak pekerjanya untuk terpenuhi sangatlah rendah. Dapat dikatakan dalam penerapannya tidak sesuai dengan UndangUndang Nomor. 13 Tahun 2003 tentang Ketenagakerjaan di PT Plasindo Lestari karena masih terdapat pekerja yang tidak mendapatkan haknya untuk memperoleh upah kerja lembur.

Dalam kehidupan bermasyarakat pekerjaan merupakan bagian yang dapat memberikan kehidupan yang layak bagi manusia. Hal itu pula mungkin yang menjadikan, bahwa pekerjaan adalah salah satu hak yang diakui dalam Deklarasi Universal tentang Hak Asasi Manusia tahun 1948. Pada pasal 23 dari deklarasi tersebut, ditentukan bahwa : 
ANALISIS PELAKSANAAN PERJANJIAN JAM KERJA ANTARA PERUSAHAAN DENGAN PEKERJA DI PT PLASINDO LESTARI DIHUBUNGKAN DENGAN PASAL 77 UNDANGUNDANG NOMOR 13 TAHUN 2003 TENTANG KETENAGAKERJAAN: M. Abas., Sartika Dewi, Yusuf Rizki

" Setiap orang berhak atas pekerjaan, berhak dengan bebas memilih pekerjaan, berhak ats syaratsyarat perburuhan yang adil serta baik dan atas perlindungan terhadap pengangguran, Setiap orang dengan tidak ada perbedaan, berhak atas pengupahan yang sama untuk pekerjaan yang sama, Setiap orang yang memerlukan pekerjaan berhak atas pengupahan yang adil dan baik yang menjamin penghidupannya bersama dengan keluarganya, sepadan dengan martabat manusia, dan jika perlu di tambah dengan bantuan-bantuan sosial lainnya."

Sedangkan di Indonesia hak atas pekerjaan tercantum dalam UndangUndang Dasar 1945, yaitu pada pasal 27 ayat ( 2 ) bahwa : "Tiap-tiap warga negara berhak atas pekerjaan dan penghidupan yang layak bagi Sudah lama pemerintah Indonesia mencanangkan dan mensosialisasikan hubungan kerja yang lebih manusiawi antara buruh dan pengusaha ( menurut pemerintah ) yaitu dengan konsep Hubungan Industrial Pancasila ( HIP ) yang akhirnya di tuangkan dalam pasal 1 (point 16 ) Undang-Undang Nomor 13, yang menyatakan bahwa "hubungan industrial adalah suatu sistem hubungan yang terbentuk antara pelaku dalam proses produksi barang dan/jasa yang terdiri dari unsur pengusaha, pekerja/buruh, dan pemerintah yang didasarkan pada nilai-nilai pancasila dan Undang-Undang Dasar Republik Indonesia Tahun 1945 Menepati atau/nakoming berarti memenuhi isi perjanjian. Atau dalam arti yang lebih luas lagi "melunasi" pelaksanaan isi perjanjian. Memang inilah tujuan dari setiap perjanjian yaitu memenuhi dengan sempurna segala isi, tujuan dari ketentuan sesuai dengan kehendakyang telah disetujui oleh para pihak. Untuk mengetahui hal-apa yang yang wajib dilaksanakan dapat dilihat dari beberapa sumber.

a.Dari sumber Undang-undang sendiri

Pada umumnya Undang-Undang hukuk perjanjian telah mengatur beberapa ketentuan tentang kewajiban-kewajiban yang mesti dilaksanakan dengan sempurna.

b.Sumber yang tidak kurang pentingnya ialah "akta/surat perjanjian" yang diperbuat berdasar persetujuan dan kehendaak para pihak. 
ANALISIS PELAKSANAAN PERJANJIAN JAM KERJA ANTARA PERUSAHAAN DENGAN PEKERJA DI PT PLASINDO LESTARI DIHUBUNGKAN DENGAN PASAL 77 UNDANGUNDANG NOMOR 13 TAHUN 2003 TENTANG KETENAGAKERJAAN: M. Abas., Sartika Dewi, Yusuf Rizki

c.Kewajiban kedua belah pihak dapat juga dilihat menurut tujuan dari perjanjian dan sifat perjanjian.

Untuk menentukan apakah kedua belah pihak telah melaksanakan kewajibannya memenuhi isi perjanjian, ukurannya didasarkan pada "kepatutan" atau telah melaksanakan kewajibannya menurut yang "sepatutnya" serasi dan layak menurut semestinya sesuai dengan ketentuan-ketentuan yang telah mereka setujui bersama

Pada dasarnya, setiap pengusaha harus melaksanakan ketentuan waktu kerja, sesuai dengan ketentuan pasal 77 ayat 1 . Namun pada pelaksanaannya di PT. Plasindo Lestari waktu yang dipergunakan yaitu ketentuan kerja selama 6 hari dalam 1 minggu. Namun pada pelaksanaannya, PT. Plasindo Lestari memberlakukan waktu kerja yang lebih. Yaitu 8 jam dalam 1 hari dan 45 jam dalam 1 minggu Mengenai KetidakSesuain waktu kerja pada sebuah perusahaan, waktu kerja yang diberlakukan pada PT. Plasindo Lestari tidak terikat penuh pada ketentuan yang diberlakukan sebuah perubahan bukan menjadi suatu hal yang baru. Keunikan dalam hal ini mempengaruhi sistem kerja yang diberlakukan juga dituntut untuk cepat beradaptasi dengan perubahan. Sehingga tidak dapat dipungkiri bahwa dimungkinkan adanya ketidaksesuaian yang metingakibatkan sebuah konsekuensi baik bagi perusahaan maupun bagi pihak pekerja. Yang mana mengakibatkan terjadinya ketidakseimbangan antara keduanya.

Sesuai dengan ketentuan waktu kerja yang berlaku pada PT. Plasindo Lestari yaitu menggunakan ketentuan 6 hari kerja dalam satu minggu. Namun, pada kenyataannya PT. Plasindo Lestari meberlakukan waktu kerja selama 12 jam untuk 6 hari kerja dalam satu minggu. pemberlakuan waktu kerja ini dimulai dari hari senin hingga sabtu, yaitu pukul 08.00 hingga 06.00 am dikurangi dengan 1 jam waktu istirahat. Untuk hari sabtu pekerjaan hanya dilakukan 12 jam dalam 1 hari yaitu pukul 08.00 hingga 06.00 dikurangi waktu istirahat 1 jam. Jika di total, maka PT. Plasindo Lestari memberlakukan 72 jam waktu kerja dalam 1 minggu

Disini dapat dikatakan bahwa PT. Plasindo Lestari tidak memberlakukan ketentuan waktu kerja yang sesuai dengan Pasal 77 ayat 1 Undang-Undang No 13 tahun 2003 Tentang Ketenagakerjaan. 
ANALISIS PELAKSANAAN PERJANJIAN JAM KERJA ANTARA PERUSAHAAN DENGAN PEKERJA DI PT PLASINDO LESTARI DIHUBUNGKAN DENGAN PASAL 77 UNDANGUNDANG NOMOR 13 TAHUN 2003 TENTANG KETENAGAKERJAAN: M. Abas., Sartika Dewi, Yusuf Rizki

Menurut Ketentuannya, waktu kerja yang sesuai dengan ketentuan adalah 40 jam dalam 1 minggu, jika ada waktu yang melebihi waktu tersebut maka dapat dikategorikan sebagai waktu lembur. Namun, yang menjadi permasalahan disini yaitu PT. Plasindo Lestari ketidaksesuain Jam kerja yang melebihi waktu dan untuk mengenai waktu lembur PT Plasindo Lestari pembayaran waktu lembur tidak pernah dibayar sesuain dengan kesepakatan Perusahaan dan Pekerja.

Jika dikaitkan dengan undangundang yang berlaku, efek yang terjadi adalah kerugian yang dialami karyawan didasarkan pada ketentuan pasal 78 ayat 1 dan 2 yang menyebutkan bahwa pengusaha yang mempekerjakan buruh/pekerja melebihi waktu kerja yang sebagaimana ditentukan pada pasal 77 harus ada persetujuan dengan buruh/pekerja yang bersangkutan dan wajib membayar upah lembur. kerja lembur, pengaturannya PT Plasindo Lestari langsung (secara lisan) yang didapatkan:

Mengenai waktu kerja di PT Plasindo Lestari yang mulai bekerja dari pukul 8.00 pagi sampai dengan pukul 20.00 terbagi atas beberapa shift/waktu kerja sebagai berikut:

a.shift 1 dari pukul 08.00 sampai dengan pukul 16.00,

b.shift 2 dari pukul 16.00 sampai dengan pukul 23,55

c.shift 3 dari pukul 23. 55 sampai dengan pukul 08.00,

Lama bekerja pada setiap shift adalah selama 8 jam, dengan waktu istirahat selama 1 jam setiap harinya (mengacu pada ketentuan 8 jam kerja setiap harinya untuk 6 hari kerja dalam satu minggu), dan mendapatkan waktu libur resmi dalam satu minggu selama 1 (satu) hari kerja diluar waktu libur dari ketentuan libur resmi Peraturan Kerja Bersama.

Dari waktu kerja yang disampaikan ada beberapa kekurangan ditinjau dari waktu kerja yang seharusnya, seperti:

pekerja diminta memulai pekerjaan tepat pada saat dimulainya waktu kerja dan mengakhiri pekerjaan sampai dengan selesai tanggungjawab yang telah ditetapkan pada hari itu. Dan agar dapat memulai pekerjaan tepat sesuai dengan jam kerjanya, pekerja wajib telah berada di tempat kerja masing- 
ANALISIS PELAKSANAAN PERJANJIAN JAM KERJA ANTARA PERUSAHAAN DENGAN PEKERJA DI PT PLASINDO LESTARI DIHUBUNGKAN DENGAN PASAL 77 UNDANGUNDANG NOMOR 13 TAHUN 2003 TENTANG KETENAGAKERJAAN: M. Abas., Sartika Dewi, Yusuf Rizki

masing sekurang-kurangnya 10 menit sebelum waktu kerja. Pekerja yang tiba pada saat dimulai atau setelah dimulai waktu kerja dianggap terlambat dan akan dikenakan sanksi.

pekerja diminta tidak langsung meninggalkan tugasnya jika pekerjaan yang menjadi tanggung jawabnya tidak dapat ditunda sampai hari besoknya seperti pada pengecekan antara jumlah barang yang harus diterima pada hari itu, jumlah jam kerja kadangkala lebih dari 2 jam, dan ini terjadi rutin setiap setiap hari/setiap bulan paling tidak, bisa mencapai frekwensi 3 kali dalam satu minggu bahkan lebih, mendapatkan lembur lebih yang melebihi ketentuan Undang-Undang Nomor 13 Tahun 2003 Tentang KetenagaKerjaan pada Pasal 77

Pekerja dilarang meninggalkan tugasnya jika belum ada penggantian shift, Jumlah jam kerja kadangkala lebih dari 2 jam sampai pekerja tadi tidak mendapatkan uang lembur, dengan alasan Pihak Perusahaan tidak ingin membayar pekerja melebihi waktu kerja lembur dan pihak pekerja sendiridi tuntut untuk bekerja selama 12 jam secara terus menerus oleh pihak manajemen perusahan PT Plasindo Lestari.

Sering terjadi bagi pekerja Produksi, karena beban pekerjaan yang dengan tibatiba menjadi bertambah, misalnya ada permintaan dari Manajemen untuk meminta data stok barang harus selesai pada saat itu juga, karena akan digunakan untuk pengiriman Urgent pada custamer, yang seharusnya pekerja bisa pulang atau istirahat sesuai jam normal menjadi tidak jelas lagi waktu pulangnya karena harus tetap bekerja sesuai permintaan pihak manajemen perusahaan,Hal ini sering terjadi dan mengakibatkan tekanan psikologis bagi karyawan PT Plasindo Lestari.

Untuk pekerja lembur yang melebihi jam kerja hanya diberikan pada level tertentu (Helper) saja, dengan pengaturan sesuai ketentuan Perjanjian Kerja Bersama Ketentuan lembur sebagai berikut:

a. untuk waktu kerja, melebihi waktu kerja normal maksimal 2 jam kerja,

b. pada waktu hari libur resmi yang ditetapkan oleh Perjanjian Kerja Bersama 
ANALISIS PELAKSANAAN PERJANJIAN JAM KERJA ANTARA PERUSAHAAN DENGAN PEKERJA DI PT PLASINDO LESTARI DIHUBUNGKAN DENGAN PASAL 77 UNDANGUNDANG NOMOR 13 TAHUN 2003 TENTANG KETENAGAKERJAAN: M. Abas., Sartika Dewi, Yusuf Rizki

Berdasarkan wawancara kepada Bapak Agus Sustrisno Selaku Kepala Bagian Bag Making yang telah dilakukan penulis dengan menjadikan faktor yang berada di PT Plasindo Lestari, dapat dikatakan bahwa beberapa faktor yang mempengaruhi pengusaha dalam memberikan upah terhadap pekerja yang ada dalam lingkungan pekerja seperti meningkatnya produksi Bag Making sehingga melonjaknya Orderan dari pihak Customer kepada pihak PT Plasindo halnya faktor Karyawan, waktu kerja, beban kerja, dan pengalaman kerja hal ini didasarkan pada wawancara penulis terhadap informasi pekerjaan dan beban kerja yang sama namun memiliki upah yang relatif berbeda, namun dalam Pasal 77 Undang-Undang Nomor. 1 Tahun 2003 tentang Ketenagakerjaan dijelaskan bahwa setiap pekerja memperoleh perlakuan yang sama tanpa diskriminasi yang artinya tiap pekerja mempunyai hak yang sama.

Menurut Penulis ketidaksesuain jam kerja di PT Plasindo Lestari meningkatnya tingkat produksi permintaan dari costumer atau buyer dan minimnya tenagakerja yang ada di PT Plasindo Lestari sehingga pekerja bekerja secara terus menerus faktor ini menjadikan ketidaksesuain isi perjanjian kerja bersama antara pekerja dengan perusahaan yang seharusnya di pasal 77 mengenai jam kerja pada waktu kerja 7 (Tujuh) jam 1 (satu) hari dan 40 (Empat puluh) jam dalam 1 (satu) minggu untuk 6 (enam) hari kerja dalam 1 (satu) minggu namun secara aktualnya dilapangan mengenai jam kerja pekerja harus bekerja 1 (satu) hari 12 (dua belas) jam dan 1 (Satu minggu) 72 (Tujuh puluh dua ) Jam untuk 6 (enam) hari kerja dalam 1 (satu) minggu.

\section{KESIMPULAN}

1. Pelaksanaan perjanjian kerja di PT. Plasindo Lestari mengenai waktu kerja perusahaan sering menentukan waktu kerja secara sepihak atau tidak sesuai dengan perjanjian kerja Ketika jumlah permintaan barang banyak melakukan penentuan waktu kerja sepihak kepada pekerja yang bekerja di bagian teknisi dan peleburan kemasan plastik. Dan ketika jumlah permintaan barang melonjak penentuan waktu kerja sepihak berlaku untuk semua pekerja, akan tetapi yang sering terjadi berlaku bagi pekerja di bidang Bag Making dan Printing Jika dikaitkan dengan Undang-Undang Nomor 13 
ANALISIS PELAKSANAAN PERJANJIAN JAM KERJA ANTARA PERUSAHAAN DENGAN PEKERJA DI PT PLASINDO LESTARI DIHUBUNGKAN DENGAN PASAL 77 UNDANGUNDANG NOMOR 13 TAHUN 2003 TENTANG KETENAGAKERJAAN: M. Abas., Sartika Dewi, Yusuf Rizki

Tahun 2003 Pasal 77 tentang waktu kerja dengan adanya penentuan waktu kerja sepihak terjadi setelah perjanjian kerja yang disepakati maka tidak sesuai dengan pasal 77 ayat 1 dimana pekerja sering tidak dipekerjakan tanpa adanya batasan waktu dan tidak diatur secara jelas, padahal pekerja bersedia melaksanakan pekerjaan/kewajibannya.

2. Yang terjadi di PT. Plasindo Lestari dalam pelaksanaan perjanjian kerja, salah satu syarat sahnya suatu perjanjian yakni tidak jelas dan gamblang saat melaksanakan perjanjian kerja. sehingga hak-hak pekerja tidak terpenuhi sesuai dengan perjanjian kerja yang disepakati diantaranya: pekerja tidak mendapatkan pekerjaan yang dijanjikan, sehingga berpengaruh pada besaran upah.

\section{Saran}

1. Adanya tranparasi dari pengusaha dalam memberikan informasi yang utuh mengenai kinerja perusahaan secara berkala dan diperjelas pula peran dan posisi pekerja/buruh dalam memberikan kontribusi kepada perusahaan. hal ini dapat memotivasi pekerja/buruh agar lebih berorientasi kepada produktifitas.

2. Menguatkan pekerja/buruh yang sesuai dengan budaya perusahaan itu sendiri dengan membangun nilai-nilai kebersamaan sebagai fondasi hubungan industrial, dengan demikian dapat mendorong percepatan demokratisasi di setiap perusahaan dan akhirnya dapat memperjuangkan aspirasi politiknya dengan terbentuknya organisasi pekerja/buruh yang solid. dari dalam diri pekerja harus memahami pentingnya kesadaraan untuk melindungi hak-haknya.

\section{DAFTAR PUSTAKA}

\section{A.Buku}

Abdul Khakim, Dasar-Dasar Hukum Ketenagakerjaan Indonesia,PT Citra Aditya Bakti, Bandung, 2009.

- $\quad$ Pengantar Hukum Ketenagakerjaan Indonesia Berdasarkan UndangUndang Nomer 13 Tahun 2003, Bandung: PT. Citra Aditya Bakti, 2003

Abdul Rachmad Budiono, Hukum

Perburuhan Indonesia, PT

RajaGrafindo Persada, Jakarta, 2008. 
ANALISIS PELAKSANAAN PERJANJIAN JAM KERJA ANTARA PERUSAHAAN DENGAN PEKERJA DI PT PLASINDO LESTARI DIHUBUNGKAN DENGAN PASAL 77 UNDANGUNDANG NOMOR 13 TAHUN 2003 TENTANG KETENAGAKERJAAN: M. Abas., Sartika Dewi, Yusuf Rizki

Subekti, Hukum Perjanjian, Jakarta 2002,PT,Intermasa.

\section{B.Perundang-Undangan}

Kitab Undang-Undang Hukum Perdata

Undang-UndangNomor 13 Tahun 2003

Tentang KetenagaKerjaan

Peraturan Pemerintah Nomor. 8 tahun 1981

Tentang Perlindungan Upah.

Peraturan Pemerintah Nomor 78 Tahun 2015 tentang Pengupahan

\section{C.Sumber Lainnya}

\section{Jurnal}

Cadra Tofik Nurcahya,Universitas Muhammadiyah Surakarta Tahun 2014,Tinjauan Yuridis Konstruksi Hukum Perjanjia Kerja Karyawan Pada Perusahaan Daerah BPR BANK Boyolali Prespektif UndangUndang Nomor 13 Tahun 2003 Tentang KetenagaKerjaan.

Diyah Handayani, Fakultas Syari,ah Universitas Negri Walisongo Semarang 2014, Tinjaun Hukum Islam Terhadap Pelaksanaan Jam Kerja Karyawan Di TB. Sederhana Di Desa Guntur Kecamatan Guntur Kabupaten Demak

Dr. Kelik Wardiono, S.H., M.H (2019) Tinjauan Yuridis Perjanjian Kerja Di PT. Java Textile
Garmindo Di Sukoharjo. Skripsi thesis, Universitas Muhammadiyah Surakarta.

M. Nasir, FAKULTAS HUKUM UNIVERSITAS STIKUBANK SEMARANG 2011. PELAKSANAAN PERJANJIAN KERJA WAKTU TERTENTU (PKWT) DI PT SANDANG ASIA MAJU ABADI

Muhammad Kanzunuddin. 2007. Pengaruh Upah daan Pengawasan Terhadap Produktivitas Karyawan studi Ksus PT. Tonga Tiur Putra di Kabupaten Rembang. Jurnal Ekonomi Fokus Ekonomi Vol 2 No. 1, STEPARI

\section{Internet}

http://eprints.ums.ac.id/30384/1/HALAMA

N_DEPAN.pdf diakses pada tanggal

8 Oktober 2020 Pada Pukul 1:12

http://jhp.ui.ac.id/index.php/home/article/vi ewFile/443/378 diakses pada tanggal 17 Oktober 2020 Pada pukul 12:35 